\title{
Brazilian postgraduate programs in Food and Nutrition: Considerations on evaluation procedures
}

\section{A pós-graduação no campo da Alimentação e Nutrição no Brasil: considerações sobre procedimentos de avaliação}

Rossana Pacheco da Costa PROENÇA ${ }^{1}$ iD 0000-0001-6149-8752

Shirley Donizete PRADO² ID 0000-0001-5848-5766

Ligia AMPARO-SANTOS 3 iD 0000-0002-6925-6421

Anabelle RETONDARIO1 ${ }^{1}$ D 0000-0002-8809-5627

Juliede de Andrade ALVES ${ }^{3}$ (D) 0000-0003-2389-3908

Liv Katyuska de Carvalho Sampaio de SOUZA2 (iD) 0000-0002-3436-0376

\section{A B S T R A C T}

This essay aims to present some considerations on the development of research and teaching skills, intellectual production, and current situation of stricto sensu postgraduate programs in Food and Nutrition, particularly of professional and academic master's and doctoral programs currently classified in the evaluation category Nutrition by the Coordenação de Aperfeiçoamento de Pessoal de Nivel Superior. The elements of evaluation procedures are discussed, as are the scores given to the programs in the most recent Coordenação de Aperfeiçoamento de Pessoal de Nivel Superior report. There was a marked increase in the participation of Food and Nutrition postgraduate programs in the national context. Many challenges still need to be overcome, such as the offer of

${ }^{1}$ Universidade Federal de Santa Catarina, Centro de Ciências da Saúde, Programa de Pós-Graduação em Nutrição. Campus Universitário, s/n., Trindade, 88040-900, Florianópolis, SC, Brasil. Correspondence to: RPC PROENÇA. E-mail: <rossana.costa@ufsc.br>.

${ }^{2}$ Universidade do Estado do Rio de Janeiro, Instituto de Nutrição, Programa de Pós-Graduação em Alimentação, Nutrição e Saúde. Rio de Janeiro, RJ, Brasil.

${ }^{3}$ Universidade Federal da Bahia, Escola de Nutrição, Programa de Pós-Graduação em Alimentos, Nutrição e Saúde. Salvador, BA, Brasil.

How to cite this article

Proença RPC, Prado SD, Amparo-Santos L, Retondario A, Alves JA, Souza LKCS. Brazilian postgraduate programs in Food and Nutrition: Considerations on evaluation procedures. Rev Nutr. 2019;32:e180226. http://dx.doi.org/10.1590/1678$9865201932 \mathrm{e} 180226$ 
Nutrition postgraduate programs in the Northeast region and outside the capital cities of the country. Evaluation criteria and procedures need to be better developed to consider the main characteristic of the scientific field of Food and Nutrition, its multiplicity of disciplines.

Keywords: Feeding. Nutritional Sciences. Research. Research personnel. Scientific domains.

\section{R E S U M O}

Este ensaio tem por objetivo apresentar algumas considerações acerca da formação para a pesquisa e docência, da produção intelectual e do panorama atual da pós-graduação Stricto sensu no campo da Alimentação e Nutrição a partir do recorte empírico correspondente aos cursos de mestrado acadêmico e profissional e de doutorado, atualmente inseridos na Área de Avaliação Nutrição na Coordenação de Aperfeiçoamento de Pessoal de Nível Superior. São discutidos elementos dos processos de avaliação desses programas, abordando os já citados aspectos e discutindo os conceitos conferidos aos programas em questão na última avaliação. Em suma, observou-se que a pesquisa e a pós-graduação em Alimentação e Nutrição aumentaram sua expressão no contexto nacional, restando muitos desafios a serem superados, como sua presença no interior do país e na Região Norte, em especial. Quanto à avaliação dos Programas, entende-se que permanece a necessidade de construção de critérios e procedimentos que atendam à principal característica identitária do campo científico da Alimentação e Nutrição: sua multiplicidade disciplinar.

Palavras-chave: Alimentação. Ciências da Nutrição. Pesquisa. Pesquisadores. Domínios científicos.

\section{INTRODUCTION}

The aim of this essay is to present some considerations on the development of research and teaching skills, intellectual production, and current situation of stricto sensu postgraduate programs in Food and Nutrition, particularly of professional and academic master's and doctoral programs currently in the evaluation category Nutrition of the Coordenação de Aperfeiçoamento de Pessoal de Nivel Superior (CAPES, Coordenation for Higher Educational Staff Development). This effort is based on the authors' accumulated experience from working as teachers, researchers, postgraduate coordinators, heads of the Fórum Nacional de Coordenadores de Programas de Pós-Graduação em Alimentação e Nutrição (Fórum PPG A\&N, Committee of Food and Nutrition Postgraduate Coordinators), and participants of CAPES Evaluation Committees since 2000.

The field of Food and Nutrition is inserted in several spaces of the Brazilian scientific community. There are postgraduate programs and research lines focused on nutrients, food, and diet in several of CAPES evaluation categories [1,2]. Until 2011, postgraduate courses now in the category Nutrition were classified in the category Medicine II by CAPES and were thus subject to the evaluation criteria of that area. The academic community highly criticized this evaluation method [3]. It was argued that the multifaceted, multidisciplinary, and multi-epistemic Food and Nutrition programs needed to be viewed differently from biomedical programs and that evaluation procedures needed to consider the specific aspects of each area related to scientific research and the formation of masters and doctors [4].

For a long period, this debate remained limited to professors and students involved in the production of knowledge and research and teaching skills in Food and Nutrition. In 2001, a round table discussion was held at the VI National Congress of the Sociedade Brasileira de Alimentação e Nutrição (SBAN, Brazilian Food and Nutrition Society) in Florianópolis, Brazil. Food and Nutrition researchers and representatives of CAPES and the Conselho Nacional de Desenvolvimento Científico e Tecnológico (CNPq, National Council for Scientific and Technological Development) were brought 
together to discuss the need to create specific evaluation committees for the scientific field of Food and Nutrition within these institutions [5]. In 2006, the first meeting of coordinators of Food and Nutrition postgraduate programs was held in Salvador, Brazil. The participants agreed on the need to strengthen the field and improve the programs, working toward the creation of a CAPES evaluation category for Food and Nutrition [4].

These meetings were held periodically, and in 2008, in Rio de Janeiro, Brazil, the Fórum PPG A\&N was created. At the time, it was considered that the debate on the need for epistemological distinction between postgraduate programs in Food and Nutrition and in Medicine was sufficiently mature [2]. The interdisciplinary character and indispensable dialogue with the various fields of knowledge were viewed as ontological elements of this scientific area. Furthermore, the creation of a specific CAPES evaluation category would boost the creation of new programs, help make it possible to meet the demands of the country's Food and Nutrition agenda, and stimulate scientific production [4]. It was considered that the field of Food and Nutrition was already sufficiently organized and capacitated to maintain a trajectory in spaces already marked by strong scientific capital [2].

Discussions and the process of articulation were intensified with the official request to create a specific CAPES evaluation category in 2009 and continued until the $6^{\text {th }}$ meeting of the Forrum PPG A\&N, held in 2011, in Florianópolis, Brazil [4]. Finally, the CAPES evaluation category Nutrition was created through Ordinance No.83 of June 6, 2011. Since then, specific rules have been established for evaluating existing postgraduate programs and creating new programs, regulating their participation within the institutional place [4].

The 2010-2012 triennial CAPES evaluation was marked by the transition from Medicine II to Nutrition [6]. It was expected that the evaluation criteria would be better adapted to the specificities of Food and Nutrition programs by the next evaluation period, 2013-2016 [7], as a continuation of the debates and discussions that led to the creation of the new evaluation category.

Analysis of past trends can provide a global view of recent scenarios and focus points. Table 1 shows the number of postgraduate programs in Nutrition since the creation of the first course in 1971. In the first two decades, there was a slow increase in the number of programs. From the 1990s, the number begins to rise, and from 2006 onwards there is a marked increase, following the trends of other Brazilian stricto sensu postgraduate courses. The beginning of the increase coincides with the establishment of the Fórum PPG A\&N, whose meetings focused on the implementation of activities to stimulate and guide the creation of new programs $[3,8]$. The favorable results of this initiative were further supported by the creation of the Nutrition evaluation category by CAPES in 2011, confirming what had been discussed about the evaluation method and the projections that preceded this event [4].

Currently, postgraduate programs in Nutrition are present in various regions of the country, except for the North, as shown in Table 2. The number of courses is not proportional to the population distribution. The Southeast holds more postgraduate programs than the other regions. However, in terms of number of inhabitants per programs, the South has the highest offer, 4.9 million inhabitants/program, followed by the Central-West (5.6 million inhabitants/program), Southeast (6.2 million inhabitants/program), and Northeast (7.09 million inhabitants/program) [9]. Unfortunately, the programs are not distributed according to the economic, social, education, and health care demands of the Brazilian population. We highlight the importance of creating more programs and investing in existing ones, especially in regions where social demands are greater. The Northeast had only one doctoral course in Nutrition until 2013. Since then, three new doctoral courses were created, but 
this number is still insufficient. The same applies to the South, where only in 2018 was a second doctoral course in Nutrition established. Attention should be focused on the North, which does not have a postgraduate program in Nutrition and remains an institutional challenge. Recent policies have focused on offering public higher education, including masters and doctoral courses, outside the capital cities of the country. In the Northeast, for example, only one postgraduate program is not offered in a capital city.

Table 1. Postgraduate courses in Nutrition in Brazil from 1971 to 2018. Postgraduate programs in Nutrition were classified by the Coordenation for Higher Education Staff Development (CAPES) in the evaluation category Medicine II until 2010 and in the category Nutrition as of 2011.

\begin{tabular}{|c|c|c|c|c|c|c|c|c|c|c|}
\hline \multirow{2}{*}{ Course* $^{*}$} & \multicolumn{10}{|c|}{ Year } \\
\hline & 1971 & 1985 & 1991 & 1995 & 2000 & 2001 & 2002 & 2005 & 2006 & 2008 \\
\hline Master's & 1 & 2 & 4 & 5 & 6 & 7 & 8 & 10 & 10 & 12 \\
\hline Doctoral & 0 & 0 & 3 & 3 & 3 & 3 & 3 & 3 & 4 & 4 \\
\hline Professional Master's & 0 & 0 & 0 & 0 & 0 & 0 & 0 & 0 & 0 & 0 \\
\hline Total & 1 & 2 & 7 & 8 & 9 & 10 & 11 & 13 & 14 & 16 \\
\hline \multirow{2}{*}{ Course $^{*}$} & \multicolumn{10}{|c|}{ Year } \\
\hline & 2009 & 2010 & $2011^{* *}$ & 2012 & 2013 & 2014 & 2015 & 2016 & 2017 & 2018 \\
\hline Master's & 13 & 15 & 18 & 18 & 18 & 22 & 23 & 24 & 27 & 28 \\
\hline Doctoral & 5 & 7 & 7 & 8 & 9 & 11 & 11 & 11 & 12 & 11 \\
\hline Professional Master's & 0 & 0 & 0 & 1 & 3 & 3 & 3 & 3 & 3 & 3 \\
\hline Total & 18 & 22 & 25 & 27 & 30 & 36 & 37 & 38 & 42 & 42 \\
\hline
\end{tabular}

Note: ${ }^{*}$ A program may have one or more postgraduate courses; ${ }^{* *}$ Year of introduction of the evaluation category Nutrition in the CAPES classification system [4].

Source: Prado et al. [1]; Brazil [11]; Souza [13].

Table 2. Postgraduate programs in Nutrition from 1998 to 2018 in Brazil by region. Postgraduate programs in Nutrition were classified by the Coordenation for Higher Education Staff Development (CAPES) in the evaluation category Medicine II until 2010 and in the category Nutrition as of 2011

\begin{tabular}{|c|c|c|c|c|c|c|c|c|c|c|c|c|}
\hline \multirow{3}{*}{ Region } & \multicolumn{12}{|c|}{ Evaluation period } \\
\hline & \multicolumn{2}{|c|}{$1998-2000$} & \multicolumn{2}{|c|}{$2001-2003$} & \multicolumn{2}{|c|}{$2004-2006$} & \multicolumn{2}{|c|}{$2007-2009$} & \multicolumn{2}{|c|}{$2010-2012$} & \multicolumn{2}{|c|}{$2013-2018^{*}$} \\
\hline & $\mathrm{n}$ & $\%$ & $\mathrm{n}$ & $\%$ & $n$ & $\%$ & $n$ & $\%$ & $n$ & $\%$ & $n$ & $\%$ \\
\hline Southeast & 3 & 50.0 & 4 & 50.0 & 4 & 40.0 & 5 & 38.0 & 11 & 42.0 & 14 & 45.0 \\
\hline Northeast & 2 & 33.0 & 2 & 25.0 & 4 & 40.0 & 4 & 32.0 & 7 & 27.0 & 8 & 26.0 \\
\hline South & 0 & 0.0 & 1 & 12.5 & 1 & 10.0 & 2 & 15.0 & 5 & 19.0 & 6 & 19.0 \\
\hline Central-West & 1 & 17.0 & 1 & 12.5 & 1 & 10.0 & 2 & 15.0 & 3 & 12.0 & 3 & 10.0 \\
\hline North & 0 & 0.0 & 0 & 0.0 & 0 & 0.0 & 0 & 0.0 & 0 & 0.0 & 0 & 0.0 \\
\hline Total & 6 & 100.0 & 8 & 100.0 & 10 & 100.0 & 13 & 100.0 & 26 & 100.0 & 31 & 100.0 \\
\hline
\end{tabular}

Note: *Includes all postgraduate programs reported in the 2013-2016 CAPES evaluation as well as new programs registered until May 2018. Source: Prado et al. [1]; Brazil [11]; Souza [13].

A similar scenario is seen in other CAPES evaluation categories, such as Public Health. Although located in all parts of Brazil, the programs are mainly concentrated in the Southeast. Those located in the Northeast and Central-West score lower in CAPES evaluation processes [10]. 
It should also be noted that the CAPES Nutrition evaluation category has the second lowest number of postgraduate programs in the country $(n=32)$, second only to Religion and Theology Sciences ( $n=21)$ and followed by Anthropology/Archaeology $(n=33)$ [11].

In short, the Nutrition evaluation category has a small number of programs and has been growing more intensively in recent times. Initially organized around an active, nationwide entity, the scientific field gained its own space in CAPES, which implied a transition in the procedures for program evaluation. We focus our analysis on the procedures adopted in the last two CAPES evaluations, since the creation of the Nutrition category.

For the following considerations, we emphasize that the results of the most recent CAPES evaluation (2013-2016) [7] only included relative indicators and numbers but not absolute values, unlike in previous reports $[6,12]$. This precludes longitudinal analysis of data and, consequently, global assessment of current trends in the formation of masters and doctors. Making this information public would increase the transparency of the collaborative evaluation process and allow a critical analysis by postgraduate programs on the evaluation procedures adopted.

\section{Teaching and Research Education}

As the number of postgraduate programs increased, there was a quantitative increase in the number of master's and doctoral degrees awarded in the field of Food and Nutrition (Figure 1). However, the number stabilized over the past few years, probably because many programs are new, thus some time is needed for participants to complete the degrees. With the creation of new doctoral

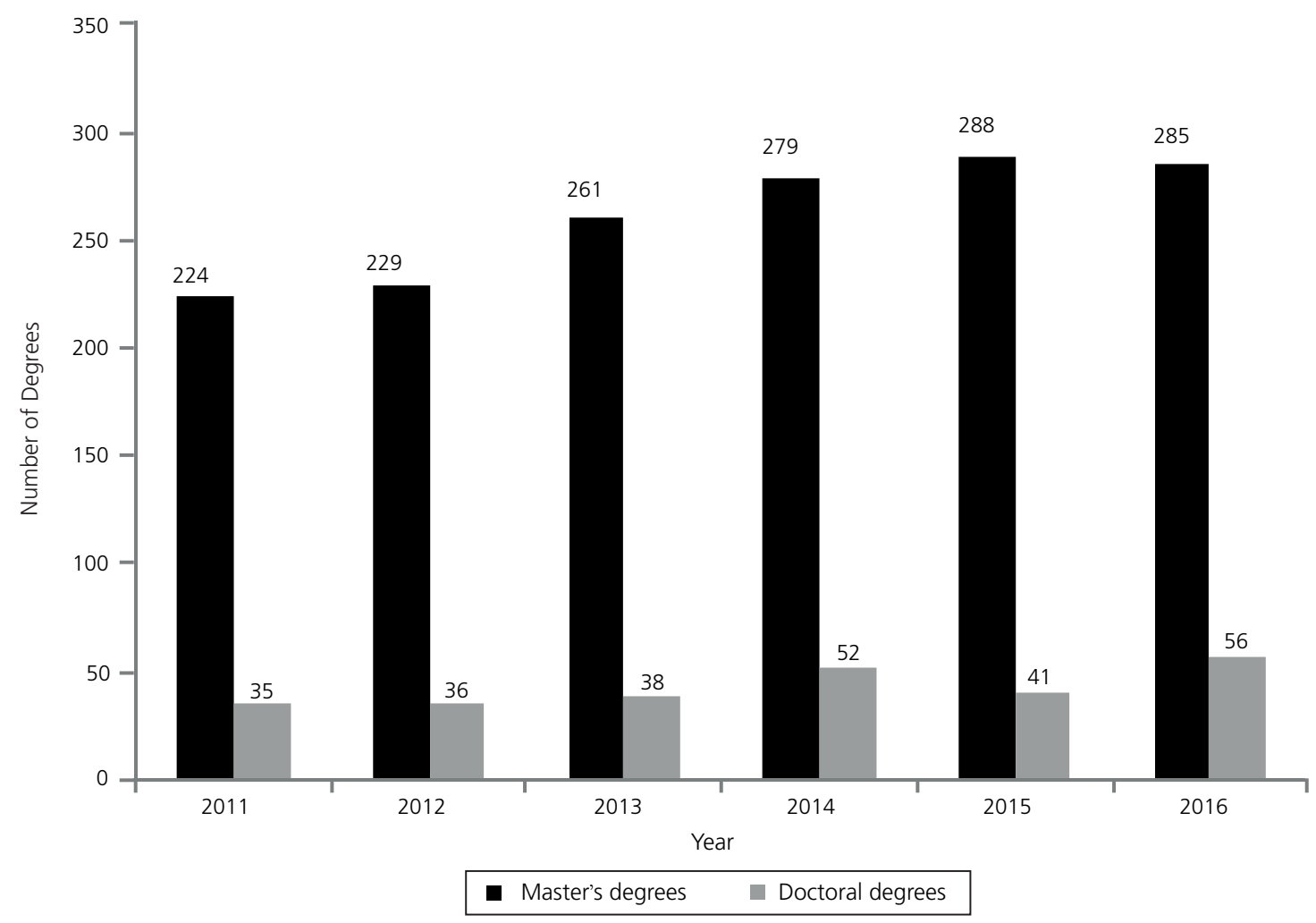

Figure 1. Number of master's and doctoral degrees in Nutrition awarded from 2011 to 2016 in Brazil.

Source: Coordenação de Aperfeiçoamento de Pessoal de Nível Superior [7] 
programs, the number of openings for doctoral courses will probably increase in detriment to the number of openings for master's courses.

There is a great need to discuss, not only the number of degrees, program duration, and number of publications, but also the quality of postgraduate programs, which still seems to be barely visible in the CAPES evaluation processes and, in our view, still little considered in the new Nutrition evaluation category.

The importance of program quality is made evident by recent studies that identified gaps in teaching training by analyzing curricula and the perspective of Nutrition postgraduates $[13,14]$. A survey carried out in 2012 with Nutrition master's graduates showed that the lack of pedagogical training was one of the main complaints, followed by the lack of time for pedagogical studies because of the pressure to complete the program as quickly as possible. Although a teaching internship is mandatory in some courses, the master's graduates pointed out that there was no reflection on the practice, that is "[...] the 'doing' was satisfactory but was not accompanied by the 'know-how' "[14] (p.731, our translation). The increase in the number of master's and doctoral courses intensifies the challenges of evaluating the quality of postgraduate programs.

\section{Intellectual Production}

In its periodic evaluation, CAPES analyzes, among other parameters, the intellectual production of postgraduate programs, including scientific articles, books, and book chapters authored by teachers. The co-participation of postgraduate students is gaining increasing importance in the evaluation of intellectual production. Historically, biomedical postgraduate programs have given more importance to papers published in journals that disseminate internationally relevant topics, are indexed in international databases, and quantify citation impact, whereas, in the field of humanities, postgraduate programs have focused their production on books [15-17].

\section{Qualis Journals: The CAPES journal quality ranking}

Since 1998, CAPES use the Qualis system to assess the quality of intellectual production. According to Barradas-Barata [18], the Qualis system:

"[...] assists evaluation committees in the analysis and qualification of intellectual production by teachers and students in postgraduate programs certified by CAPES. Together with the chapter and book classification system, Qualis Periódicos is a fundamental tool for the evaluation of intellectual production, combining quantitative and qualitative aspects" (p.16, our translation).

Table 3 presents information on the intellectual production of postgraduate programs in Nutrition in Brazil according to the Qualis rank of journals in the evaluation category Medicine II for data collected from 2006 to 2010 and in the category Nutrition for data collected from 2011 onwards $[12,19,20]$. There was a marked increase in the number of articles published in higher quality journals in the triennium 2010-2012, which is probably a result of CAPES policies aimed at stimulating international publication of research results and the emphasis given to projects with a biomedical approach [21]. Note that data from the 2013-2016 report [11] are not included in Table 3 because only relative values and indicators were given in the document, as opposed to previous reports $[10,15]$, which provided both relative and absolute values of intellectual production parameters. 
Table 3. Qualis classification of articles published by postgraduate programs in Nutrition in Brazil from 2004 to 2012. Postgraduate programs in Nutrition were classified by the Coordenation for Higher Education Staff Development (CAPES) in the evaluation category Medicine II until 2010 and in the category Nutrition as of 2011.

\begin{tabular}{lccc}
\hline \multirow{2}{*}{ Qualis classification* $^{*}$} & \multicolumn{3}{c}{ Evaluation period } \\
\cline { 2 - 4 } & $2004-2006$ & $2007-2009$ & $2010-2012$ \\
\hline International A or A1 + A2 & 172 & 179 & 589 \\
International B or B1 & 90 & 228 & 739 \\
International C or B2 & 73 & 171 & 683 \\
National A or B3 & 169 & 305 & 227 \\
National B or B4 + B5 & 216 & 677 & 314 \\
National C & 116 & 12 & 91 \\
\hline Total & 836 & 1,572 & 2,643 \\
\hline
\end{tabular}

Note: *The Qualis system used different journal quality categories in different years. Corresponding categories were group together according to Prado et al. [1]. The data were collected from Coordenação de Aperfeiçoamento de Pessoal de Nível Superior (Coordenation for Higher Education Staff Development) reports.

The journal quality ranks of the Qualis system led to important considerations for improving evaluation criteria of multidisciplinary research fields, such as Food and Nutrition, as shown by the requests of different scientific fields. For instance, the 2013-2016 CAPES report was subject to debate regarding (a) the use of multiple bibliometric indicators to measure qualitatively and quantitatively citations of papers and books; (b) the strategy of promoting 4 national journals by providing the necessary assistance to foster the insertion of Brazilian vehicles for the dissemination of scientific knowledge in international spaces; and (c) the need to broaden our evaluation perspective so as to incorporate qualitative aspects and the different modes of knowledge production in a context of epistemic multiplicity [22,23]. However, this debate did not provoke changes, and evaluation criteria are now based almost exclusively on short-term (two-year) citation indicators of international journals. Such evaluation methods are widely criticized, as stated by Stephan et al. [24], "the more we bind ourselves to quantitative short-term measures, the less likely we are to reward research with a high potential to shift the frontier - and those who do it" (p.412).

Only one Brazilian journal dedicated to the field of Nutrition is indexed in international databases considered by the most recent CAPES Qualis ranking for the Nutrition evaluation category. With the adoption of metrics based only on citations, the Brazilian Journal of Nutrition was demoted to a lower level despite all efforts to improve the quality and international dissemination. The Brazilian Journal of Nutrition published the largest number of articles authored by Brazilian postgraduate academics in the area of Nutrition, according to the most recent CAPES report (2013-2016). These findings indicate that, given its specific focus on nutrition and indexation in the main databases, the Brazilian Journal of Nutrition was more relevant to the scientific area than any other national or international journal promoted to higher Qualis ranks [7].

A qualitative criterion was adopted to classify journals and allow their promotion to higher ranks, their "adherence" to the field. However, we pose the following question: what is "adherence" in a field that is ontologically multidisciplinary?

This essay shows that several important issues related to scientific publication in Nutrition remain to be solved, evidencing the need for spaces of dialogue between agents of this social space.

\footnotetext{
4 The words "promotion/promote/promoting" refer to the Portuguese words "indução/induzir" as used in CAPES evaluation reports.
} 


\section{Qualis Books: The CAPES system for ranking books and book chapters}

The quality of books and book chapters published by Nutrition academics was analyzed for the first time in the triennium 2010-2012, with the creation of the CAPES evaluation category Nutrition. This approach, received with acclaim by nutrition academics, recognizes the diversity of scientific production, knowledge, and modes of knowledge dissemination. It should be noted, however, that books and book chapters were included in the CAPES reports only in 2016, amid doubts of agents of postgraduate programs, fueled by the lack of answers to direct and public questions about the continuity of this indicator [7,12]. Finally, books and chapters were evaluated by CAPES. However, the most recent report (2013-2016) [7] presents no numerical data or indicators related to the publication of books, making it impossible to draw conclusions about the importance of this mode of knowledge dissemination among other forms of intellectual production.

We reiterate that epistemological plurality, such as valuing the publication of both books and articles, and procedural transparency are essential for a reliable evaluation of a multidisciplinary field having scientific diversity as its foundation. These issues will hopefully be addressed soon.

\section{CAPES Scores: A current overview of Postgraduate Programs}

There was a substantial increase in the number of postgraduate programs in Nutrition in the 2013-2016 period, which was accompanied by an increase in the number of programs with a CAPES score of 3 or 4 (Figure 2). During this period, the number of programs with a CAPES score of 6 (international excellence) also increased, suggesting that some may be on their way to achieve the maximum score (7). It is strategic to have a relevant number of programs in the upper

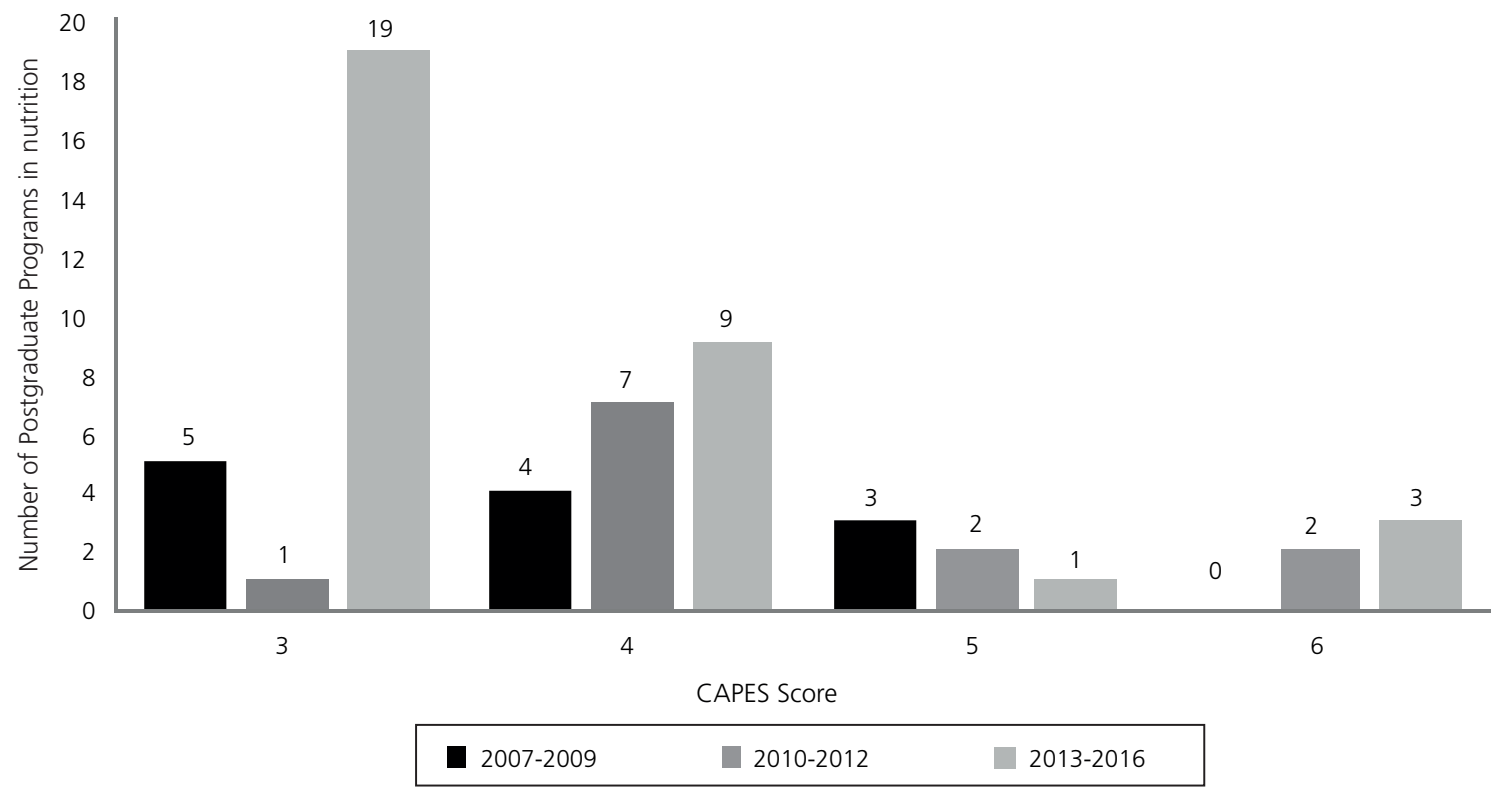

Figure 2. Coordenação de Aperfeiçoamento de Pessoal de Nível Superior score of postgraduate programs in Nutrition from 2007 to 2016 in Brazil. Postgraduate programs in Nutrition were classified by the CAPES in the evaluation category Medicine II until 2010 and in the category Nutrition as of 2011.

Source: Coordenação de Aperfeiçoamento de Pessoal de Nível Superior [7] 
intermediate level (score 5), because these courses are able to provide quality support for the formation of doctors, can stimulate the creation of novel postgraduate programs [21], and are the most promising candidates to achieve academic excellence. Furthermore, postgraduate programs with a CAPES score of 5 or more may apply for exclusive grants from national research agencies [25]. Thus, most postgraduate programs in the CAPES Nutrition evaluation category are not eligible for such assistance.

Current data indicate that the 2017-2020 period will come to an end with the same limited number of Nutrition postgraduate programs of excellence. There are few postgraduate programs competing for excellence funding and even fewer programs with upper intermediate scores. This situation limits the development of the scientific field of Nutrition as a whole.

Because it requires a differentiated approach, the professional master's degree in Nutrition was not discussed in this essay. This postgraduate degree is still incipient in Brazil and awaits consolidation of its academic/scientific purposes as well as evaluation procedures.

\section{FINAL CONSIDERATIONS}

Postgraduate programs in the field of Food and Nutrition gained new momentum from 2010 onwards with the creation of the Fórum PPG A\&N and the evaluation category Nutrition by CAPES. There was a significant increase in the number of stricto sensu courses, master's and doctoral degrees awarded, and intellectual production. Many challenges, however, still remain, such as achieving a more even distribution of programs throughout the country, especially in the Northern region of Brazil, and increasing the offer of programs outside capital cities.

This scientific field, characterized by multiplicity of disciplines, necessitates plurality in the evaluation criteria. Disregard of this important characteristic implies significant limitations in evaluating the potential and quality of the work developed in these programs.

The increase in the number of postgraduate students has expanded teacher formation but also intensified the challenges of evaluating the quality of teacher training. This has been a point of great fragility in recent evaluation procedures.

The standards set by biomedical sciences in the evaluation of knowledge production and journal quality seem to prevail in the CAPES evaluation category of Nutrition. As a result, studies of national, regional, or local interest may be unjustly relegated to a condition of academic inferiority. The lack of appreciation of Brazilian journals, especially those focusing specifically on Food and Nutrition, deserves in-depth analysis and debate. Publication of books and book chapters is now considered by CAPES, which is to be applauded, but further attention should be given to the specificities of this criterion.

The most recent CAPES report showed that few postgraduate programs in Nutrition received a high score; thus, most programs have low chances of receiving more funding and investing in actions to improve their scientific contribution.

It is necessary to organize the evaluation procedures to avoid last-minute operations. There are many activities to be carried out, and their gradual development favors the deepening of discussions on sensitive points. Transparency in data dissemination in due time for programs to analyze inconsistencies is essential, without which there is the possibility of appeal to higher bodies of CAPES. 
It is understood that clear, permanent, and open dialogue between CAPES, the Fórum PPG $A \& N$, and program coordinators about the multiple evaluation procedures is necessary to strengthen the field as a whole.

\section{CONTRIBUTORS}

All authors contributed equally to all stages of manuscript development and read and approved the final version.

\section{REFERENCES}

1. Prado SD, Martins MLR, Carvalho MCVS. A pesquisa no campo da Alimentação e Nutrição no Brasil: pluralidade epistêmica e produtividade científica. Rio de Janeiro: EdUERJ/Gramma; 2018.

2. Prado SD, Bosi MLM, Carvalho MCVS, Gugelmin SÂ, Mattos RA, Camargo Junior KR, et al. Food and nutrition as scientific field in Brazil: Concepts, domains and political projects. Rev Nutr. 2011;24(6):927-38. http://dx.doi.org/10.1590/S1415-52732011000600013

3. Kac G, Fialho E, Santos SMC. Panorama atual dos programas de pós-graduação em Nutrição no Brasil. Rev Nutr. 2006;19(6):771-84. http://dx.doi.org/10.1590/S1415-52732006000600012

4. Kac G, Proença RPC, Prado SD. A criação da área "nutrição" na Capes. Rev Nutr. 2011;24(6):905-16. http:// dx.doi.org/10.1590/S1415-52732011000600011

5. Sociedade Brasileira de Alimentação e Nutrição. Anais do VI Congresso Nacional da Sociedade Brasileira de Alimentação e Nutrição. Florianópolis: SBAN; 2001.

6. Kac G, Siqueira E, Santos S, editores. Avaliação Trienal CAPES (2010-2012): Seminário de acompanhamento dos programas de pós-graduação da área de Nutrição. Brasília: Capes; 2014.

7. Ministério da Educação (Brasil). Coordenação de Aperfeiçoamento de Pessoal de Nível Superior. Relatório de avaliação quadrienal 2017 - Nutrição. Brasília: Capes; 2017 [citado 2018 maio 28]. Disponível em: http://www. capes.gov.br/images/stories/download/avaliacao/relatorios-finais-quadrienal-2017/20122 017-NUTRICAOquadrienal.pdf

8. Kac G, Fialho E, Santos SMC, Assis AMO. Reflexões do I Fórum de coordenadores de programas de pós-graduação em nutrição no Brasil. Rev Nutr. 2006;19(6):785-92. http://dx.doi.org/10.1590/S1415-5273 2006000600013

9. Instituto Brasileiro de Geografia e Estatística. Estimativas da população residente no Brasil e Unidades da Federação com data de referência em $1^{\circ}$ de julho de 2018. Rio de Janeiro: IBGE; 2018 [citado 2018 jun 30]. Disponível em: https://www.ibge.gov.br/estatisticas-novoportal/sociais/populacao/9103-estimativas-depopulacao.html?=\&t=resultados

10. Kerr-Pontes LRS, Pontes RJS, Bosi MLM, Rigotto RM, Silva RM, Bezerra Filho JG, et al. Reflections on the evaluation of Brazilian graduate studies with an emphasis on the collective health field. Physis. 2005;15(1):83-94. http://dx.doi.org/10.1590/S0103-73312005000100005

11. Ministério da Educação (Brasil). Coordenação de Aperfeiçoamento de Pessoal de Nível Superior. Cursos avaliados e reconhecidos - 2018. Brasília: MEC; 2018 [citado 17 ago 2018]. Disponível em: https://goo.gl/ rLWH8e

12. Ministério da Educação (Brasil). Coordenação de Aperfeiçoamento de Pessoal de Nível Superior. Relatório de avaliação 2010-2012: Trienal 2013 - Nutrição. Brasília: Capes; 2013 [citado 2018 maio 28]. Disponível em: https://docs. google.com/viewer?a=v\&pid=sites\&srcid=Y2FwZXMuZ292LmJyfHRyaWVuYWwtMjAxM3xne DoxYmUwZDIkYZcwNWQ5NDVk

13. Souza LKCS. Formação para docência nos programas de pós-graduação stricto sensu no campo da Alimentação e Nutrição no Brasil [Doutorado]. Rio de Janeiro: Universidade do Estado do Rio de Janeiro; 2018. 
14. Souza LKCS, Prado SD, Ferreira FR, Carvalho MCVS. "Eu queria aprender a ser docente": sobre a formação de mestres nos programas de pós-graduação do campo da Alimentação e Nutrição no Brasil. Rev Nutr. 2014;27(6):725-34. http://dx.doi.org/10.1590/1415-52732014000600007

15. Bosi ML. Productivity and academic assessment in the Brazilian public health field: Challenges for human and social sciences research. Cad Saúde Pública. 2012;28(12):2387-92. http://dx.doi.org/10.1590/S0102-31 1X2012001400018

16. Loyola MAR. The social sciences saga in the field of collective health: Keys for reflection. Physis. 2008;18(2):251-75. http://dx.doi.org/10.1590/S0103-73312008000200004

17. Menandro PRM, Yamamoto OH, Tourinho EZ, Bastos AVB. Livros à mão cheia: o livro como veículo de produção acadêmica. Psicol USP. 2011;22(2):367-86. http://dx.doi.org/10.1590/S0103-65642011000200005

18. Barradas-Barata R. Dez coisas que você deveria saber sobre o Qualis. RBPG. 2016;13(30):13-40. http://dx. doi.org/10.21713/2358-2332.2016.v13.947

19. Ministério da Educação (Brasil). Coordenação de Aperfeiçoamento de Pessoal de Nível Superior. Relatório de avaliação 2004-2006: Trienal 2007; Medicina II. Brasília: Capes; 2007 [citado 2018 maio 28]. Disponível em: https://www.capes.gov.br/images/stories/download/avaliacaotrienal/doc_areas_trienal_2007/2007_ Medicinall_Aval2004-2006.pdf

20. Ministério da Educação (Brasil). Coordenação de Aperfeiçoamento de Pessoal de Nível Superior. Relatório de avaliação 2007-2009: Trienal 2010; Medicina II. Brasília: Capes; 2010 [citado 2018 maio 28]. Disponível em: http://trienal.capes.gov.br/wp-content/uploads/2010/12/MEDICINA-II-RELAT\%C3\%93RIO-AVALIA\% C3\%87\%C3\%830-FINAL-dez10.pdf

21. Ministério da Educação (Brasil). Coordenação de Aperfeiçoamento de Pessoal de Nível Superior. Plano Nacional de Pós-Graduação (PNPG) 2011-2020. Brasília: Capes; 2010 [citado 2018 maio 28]. Disponível em: http://www.capes.gov.br/images/stories/download/Livros-PNPG-Volume-l-Mont.pdf

22. Vasconcelos FAG. The scientific production of Nutrition published by the Scientific Electronic Library under the gaze of the evaluation of the Coordination for the Development of Higher Education Personnel. Rev Nutr. 2017;30(2):147-61. http://dx.doi.org/10.1590/1678-98652017000200001

23. Fórum Nacional de Coordenadores de Programas de Pós-Graduação em Alimentação e Nutrição. Contribuições para a formulação do Qualis Capes da área de "Nutrição" no processo de avaliação dos programas de pós-graduação para o quadriênio 2013-2016. Brasília: Fórum PPGA\&N; 2016.

24. Stephan P, Veugelers R, Wang J. Reviewers are blinkered by bibliometrics. Nature. 2017;544(7651):411-2. http://dx.doi.org/10.1038/544411a

25. Ministério da Educação (Brasil). Coordenação de Aperfeiçoamento de Pessoal de Nível Superior. Edital n²/2016: projetos de mestrado e doutorado interinstitucionais, Minter/Dinter, nacionais e internacionais. Brasília: Capes; 2016. 